\title{
VARIATION IN CEPHALIC NEUROMASTS SURFACE AND CAVE-DWELLING FISHES OF THE FAMILY AMBLYOPSIDAE (TELEOSTEI: PERCOPSIFORMES)
}

\author{
Daphne Soares ${ }^{1, C}$ and Matthew L. Niemiller ${ }^{2}$
}

\begin{abstract}
Cave adaptation has led to unique sensory specializations to compensate for the lack of visual cues in aphotic subterranean habitats. As the role of vision is reduced or disappears, other sensory modalities become hypertrophied, allowing cave-adapted organisms to successfully detect and interact with their surrounding environment. The array of aquatic subterranean habitats, from fast-flowing streams and waterfalls, to quiet phreatic pools, presents a diverse palette to examine what possible sensory solutions have evolved against a backdrop of complete darkness. Mechanosensation is enhanced in many subterranean animals to such an extent that a longer appendage is recognized as a prominent troglomorphic adaptation in many metazoans. Fishes, however, not only interact with the environment using their fins, but also with specialized sensory organs to detect hydrodynamic events. We hypothesize that subterranean adaptation drives the hypertrophy of the mechanosensory lateral line, but that other environmental forces dictate the specific neuromast phenotype. To this end, we studied differences in the cephalic lateral line of the fishes in the North American family Amblyopsidae, which includes surface, cave-facultative, and cave-obligate species. None of the taxa we examined possessed canal neuromasts on the head. Primarily surface-dwelling species, Chologaster cornuta and Forbesichthys agassizii, possessed receded neuromasts throughout most of the head, with a few on papillae located in front of the nostrils and on ventral grooves on each side of the mouth. The cavefishes Amyblopsis spelaea and Typhlichthys subterraneus possessed papillate superficial neuromasts all over the head. We speculate that the change from the surface to the cave environment has led to papillate neuromasts in this group, which are likely shaped to detect the hydrodynamic characteristics of the boundary layer created by the swimming fish. Moving sensory organs from the surface of the body out into the boundary layer could increase sensitivity to high frequency stimuli created by prey, predators, and conspecifics.
\end{abstract}

\section{Introduction}

Water currents are a pervasive feature of all aquatic environments and provide obvious cues influencing fish behaviors. Fishes themselves can also create water displacement and pressure fluctuations (Kalmijn, 1989). Hydrodynamic stimuli provide important physical and biological information about the surrounding environment, and fishes have evolved a unique mechanosensory organ to detect hydrodynamic stimuli: the mechanosensory lateral line system (Bleckmann, 1994). The lateral line system is present in all fishes but varies in morphology and distribution.

The functional unit of the lateral line is the neuromast, which can be free standing on the skin (i.e., surface or superficial neuromasts) or in canals that are open to the environments via pores (i.e., canal neuromasts). The distribution of neuromasts across the body and head determines the ability of a fish to detect moving, as well as stationary, stimuli. Each object, be it a rock or a conspecific, creates a unique hydrodynamic signature. The information gained from these hydrodynamic images influences many aspects of fish behavior. For example, fish use their lateral line to examine novel objects (Teyke, 1990; de Perera, 2004), to detect prey (Hoekstra and Janssen, 1985; Janssen, 1999; Yoshizawa et al., 2010), to monitor the movement of conspecifics (Partridge et al., 1980; Faucher et al., 2010) and predators (McHenry et al., 2009), and to maintain position in flowing water (Sutterlin and Waddy, 1975; Montgomery et al., 1997). Superficial and canal neuromasts differ in function and performance but are overlapping in hydrodynamic selectivity. Physiological studies have shown that canal neuromasts respond to water movements that are produced by moving objects, such as prey, that is maximized in the direction of the canal axis (Denton and Gray, 1989; Montgomery et al., 1994). Canal neuromasts typically occur in a distinct line at the base of a canal that runs and extends over the head and flanks. In contrast, superficial neuromasts are located on the surface of the skin and preferentially respond to the velocity of water flow that is not orthogonal to their orientation axis (van Netten and Kroese, 1989; Coombs and Montgomery, 1994; Montgomery et al., 1994) and appear to be best suited to encode flow velocity (Baker and Montgomery, 1999; Van Trump and McHenry, 2013).

The principle sensory cell of the neuromast is the hair cell (Carton and Montgomery, 2004). These hair cells have a bundle of stereovilli that grow longer from one side of the apical surface to the other. A single true kinocilium occurs in the center on of the stereovilli bundle. The stereovilli of superficial hair cells are embedded in a gelatinous matrix called

\footnotetext{
${ }^{1}$ Biological Sciences, New Jersey Institute of Technology, 100 Summit Street, Newark NJ 07102

2 Department of Biological Sciences, The University of Alabama in Huntsville, 301 Sparkman Drive NW, Huntsville, AL 35899

cCorresponding author: Soares@NJIT.edu
} 
the cupula, and the cupula is drag-coupled to the surrounding water. The motion of the hair cell bundles in the neuromast generates electrical potentials that are transduced into action potentials in afferent neurons. The relationship between cupula displacement and the amplitude of the receptor potential is linear and can reach saturation (Ćurčić-Blake and van Netten, 2006). These signals provide the central nervous system with information about water flow around the body.

The evolution of the lateral line system can be crucial for fishes to adapt to novel environments. For example, several studies have noted that species living in quieter, low-flow habitats tend to have more superficial neuromasts than species living in higher-flow habitats (Coombs et al., 1988; Teyke, 1990; Janssen, 2004). A similar response has been documented in some cavefishes, where blind cave-dwelling taxa have more superficial neuromasts than in related surface-dwelling populations that retain a functional visual system (Poulson, 1963; Niemiller and Poulson, 2010; Yoshizawa et al., 2010, 2014). It is possible that rather than being related to flow regime, morphological characteristics of the lateral line system may be an adaptive response to living in perpetual darkness in subterranean habitats. In Mexican blind cavefish, Astyanax mexicanus, superficial neuromasts are longer and more sensitive than those of related surface fish (Teyke, 1990, Yoshizawa et al., 2014), which likely contributes to their ability to better detect flow. Although it is recognized that cavefishes generally exhibit hypertrophy of the lateral line system with respect to number and size of superficial neuromasts (Soares and a,b, 2013; Niemiller and Soares, 2015), studies on neuromast morphology of cavefishes are surprisingly few (Poulson, 1960; Dezfuli et al., 2009; Jiang et al., 2016), with the most intensive work on Astyanax (Teyke, 1990; Baker and Montgomery, 1999; Montgomery et al., 2001; Yoshizawa et al. 2010, 2014).

We are interested in cephalic neuromasts specifically because they are crucial for the fine-tuning locomotion necessary for catching prey (Müller and Schwartz, 1982; Bergman, 2004; Tittel et al., 1984; Hoekstra and Janssen, 1985; Janssen, 1990, 1996; Janssen et al., 1995; Janssen and Corcoran, 1998; Schwarz et al., 2011), and they may be organized in a conformation that leads to a mechanosensory fovea (Hoekstra and Janssen, 1986, Coughlin and Strickler, 1990). These neuromasts are very diverse in morphology and organization (Coombs et al., 1994; Beckmann et al., 2010), which are often related to the environment of the fish (Higgs and Furiman, 1998; Ahnelt et al., 2004; Schmitz et al., 2014). Consequently, neuromast phenotypes can be used as a diagnostic character for species delimitation (Kurawaka, 1977; Reno, 1966; Nelson, 1972; Gosline, 1974; Parin and Astakhov, 1982; Stephens, 1985; Webb, 1989b; Arai and Kato, 2003; Bergman, 2004). Functionally, cephalic neuromasts also contribute to rheotaxis (Baker and Montgomery, 1999; Janssen, 2004) and schooling (Blaxter et al., 1983; Janssen et al., 1995; Pitcher, 2001; Diaz et al., 2003),

Here, we examine and compare the morphology of cephalic neuromasts in a family of fishes that span the ecological gradient from surface to obligate cave inhabitation-the Amblyopsidae (Actinopterygii: Teleostei: Percopsiformes). The Amblyopsidae is comprised of six genera and nine species in eastern North America (Niemiller and Poulson, 2010; Chakrabarty et al., 2014; Armbruster et al., 2016). Although subterranean adaptation in fishes is quite common (Soares and Niemiller, 2013a.b; Niemiller and Soares, 2015; for phylogeny see: Niemiller et al., 2013a,b; Armbruster et al., 2016), this family is unusual in that most species in the family are stygobiotic (obligate subterranean). The swampfish (Chologaster cornuta) is a small, pigmented species that lives in swamps of the Atlantic Coastal Plain and is the only species in the family found only in surface habitats. All other recognized species are associated with karst terrain of the Interior Low or Ozark plateaus and are at least partially cave-adapted. The spring cavefishes, Forbesichthys agassizii and $F$. papilliferus, are facultative cave inhabitants generally occurring in spring-fed streams and also caves on occasion in the Interior Low Plateau karst region (Niemiller and Poulson, 2010). All of other species in the family are obligate inhabitants of caves and have evolved a suite of morphological, physiological, and behavioral characters associated with subterranean life, most notably degeneration of eyes and reduction of pigmentation (Niemiller and Poulson, 2010; Soares and Niemiller, 2013): Northern Cavefish (Amblyopsis spelaea), Hoosier Cavefish (A. hoosieri), Alabama Cavefish (Speoplatyrhinus poulsoni), Ozark Cavefish (Troglichthys rosae), Eigenmann's Cavefish (Typhlichthys eigenmanni), and Southern Cavefish (Ty. subterraneus). In this study, we describe the morphology of cephalic neuromasts using scanning electron microscopy in four species of amblyosids and compare among cave and surface taxa: $C$. cornuta, $F$. agassizii, $A$. spelaea, and $T$. subterraneus. We hypothesize that subterranean adaptation has lead to the hypertrophy of the cephalic mechanosensory lateral line in amblyopsid cavefishes.

\section{Materials and Methods}

Individuals of four amblyopsid species were collected under scientific permits issued by the states of Tennessee (no. 1605) and Kentucky (no. SC1211135), USA in April 2012. All individuals were approximately the same size (3 cm), presumably indicating comparable developmental age, and we were not able to differentiate the sex of the fish. We collected three individuals of Forbesichthys agassizii from a quiet pool $\left(10 \mathrm{~m}^{2}\right.$, mean depth $0.6 \mathrm{~m}$, mud/silt substrate with abundant vegetation) of a spring run fed by Jarrell's Spring, Coffee Co., Tennessee, USA; three individuals of Chologaster cornuta from Colly Creek, Bladen Co., NC; three individuals for each of the two cave-dwelling species: Amblyopsis spelaea from several quiet pools (20-150 $\mathrm{m}^{2}$, mean depth $1 \mathrm{~m}$, silt/sand/cobble substrate) in Under the Road Cave, 
Breckinridge Co., Kentucky, USA and Typhlichthys subterraneus from several pools with some current (4-12 $\mathrm{m}^{2}$, mean depth $0.5 \mathrm{~m}$, cobble/bedrock substrate) in L\&N Railroad Cave, Barren Co., Kentucky, USA.

Four fishes were used for histology. Fish were euthanized by prolonged immersion in tricaine methane sulfonate (MS222, $300 \mathrm{mg} / \mathrm{L} \mathrm{pH} \mathrm{7.2)} \mathrm{then} \mathrm{perfused} \mathrm{with} 0.9 \% \mathrm{NaCl}$ followed by Alcohol-Formalin-Acetic acid (AFA). Fish were decapitated and heads were placed in AFA overnight. Heads were decalcified (RDO Gold, 20:1 ratio) under slow agitation until soft (1-2 days), were then embedded in paraffin (Paraplast X-tra) and cut at 10um thickness in a rotating microtome. Slides were rehydrated in a series of alcohol concentrations, stained with Cresyl violet for 5 minutes, rehydrated, cleared (Histoclear) and cover slipped with permount. Scanning electron microscopy (SEM) was used to differentiate and quantify the morphological features of superficial neuromasts among amblyopsid cavefishes.

Three fish of each species were euthanized by prolonged immersion in tricaine methane sulfonate (MS222, $300 \mathrm{mg} / \mathrm{L}$ $\mathrm{pH}$ 7.2). Whole specimens were fixed in $2.5 \%$ glutaraldehyde, $2 \%$ paraformaldehyde in $0.1 \mathrm{M}$ phosphate buffer. Fish were dehydrated in a series of increasingly concentrated ethanol baths before being critically point dried and spur coated with $5 \mathrm{~nm}$ of gold-palladium in a Denton Vacuum Desk II. SEM samples were imaged in an AMRAY 1620D (Bedford, MA, USA) scanning electron microscope at $10 \mathrm{kV}-30 \mathrm{kV}$ acceleration voltage. Scanning electron microscopy was performed at the

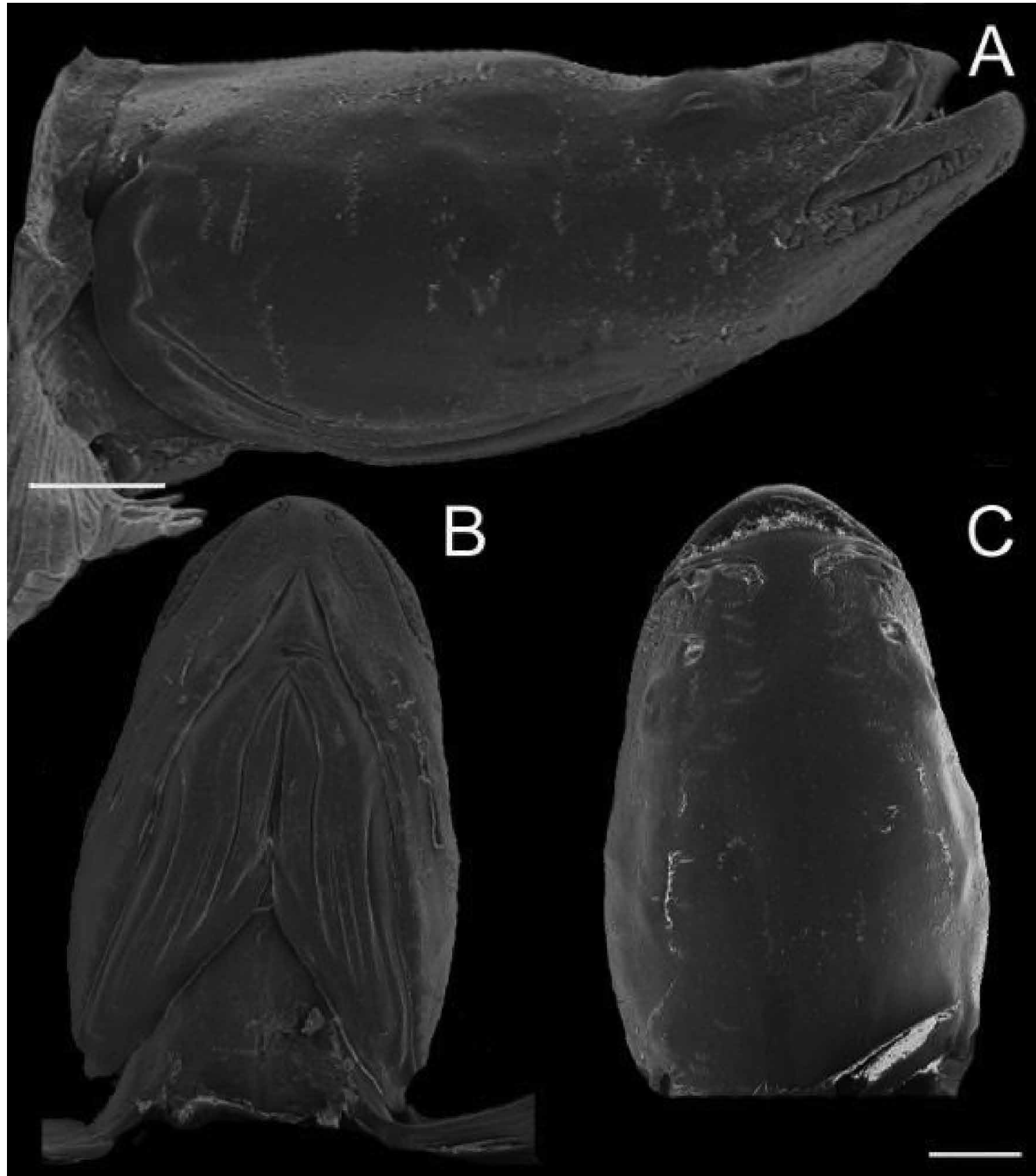

Figure 1. Lateral (A), ventral (B), and dorsal (C) SEM images of the head of Forbesichthys agassizii. Scale bar 1 $\mathrm{mm}$.
Laboratory for Biological Ultrastructure at the University of Maryland. We defined the area of the neuromast as the surface that contains the entire footprint of the cupula and the sensory plate area, as the smaller region that contains only sterocilia. Measurements were done with ImageJ (open source, https:// imagej.net). We sampled the entire head and operculum. We tested for differences in neuromast surface area, kinocilium length, and sensory plate neuromast area among species with analysis of variance followed by ad hoc Tukey HSD test using Vassarstats. net. Values reported are mean \pm 1 standard deviation.

\section{Results}

The heads of Forbesichthys agassizii (Fig. 1) 


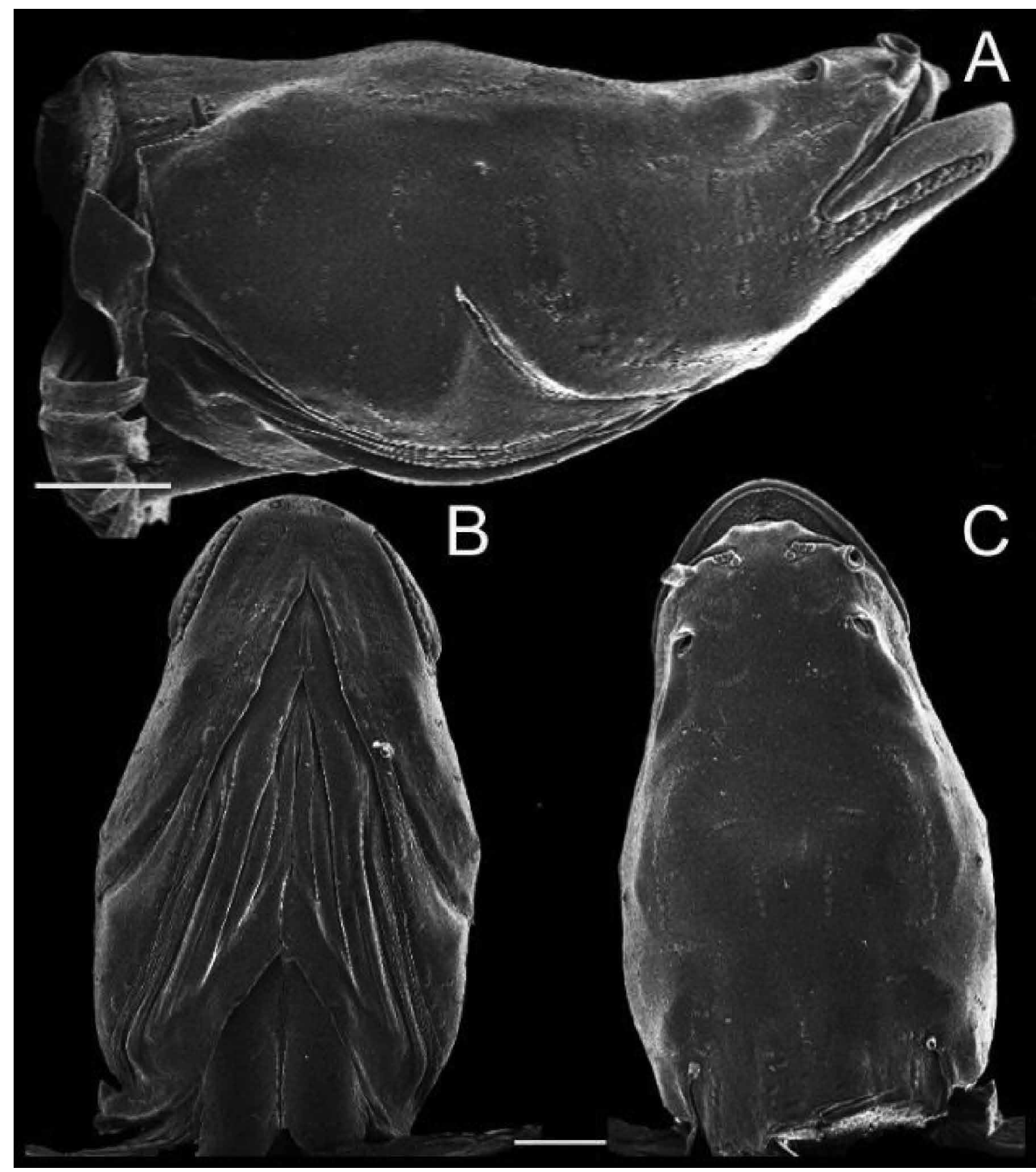

Figure 2. Lateral (A), ventral (B), and dorsal (C) SEM images of the head of Chologaster cornuta. Scale bar $1 \mathrm{~mm}$. and Chologaster cornuta (Fig. 2, see Fig. 7) were covered with stitch-like structures, positioned dorsal-ventrally. The neuromasts on the dorsal and lateral part of the head were receded into pits. The ventral side of the jaw and rostrum in both of these species were populated with superficial neuromasts on papilla. The mandibular papillae were situated in grooves that run from the tip of the lower jaw to the edge of the mouth. The mean surface area of each superficial neuromast in C. cornuta was $272.9 \pm 45.0$ $\mu \mathrm{m}^{2}$. The sensory plate, positioned in the center of the neuromast, was made up of hundreds of hair cells that occupy $131.7 \pm 9.1 \mathrm{~mm}^{2}$, or $48.3 \%$ of the neuromast area. The polarity, from shorter to longer, of the stereocilia was perpendicular to the long axis of the neuromast. The length of the kinocilium was $3.5 \pm 1.5 \mathrm{~mm}$. In F. agassizii, mean surface area was $320 \pm 40 \mathrm{~mm}^{2}$, with hair cells occupying $121.7 \pm 22.9 \mathrm{~mm}$, or $38 \%$ of the area of the sensory plate. The length of the kinocilium was $3.0 \pm 1.5 \mathrm{~mm}$. Each organ was raised above the skin on a fleshy papilla approximately $0.5 \mathrm{~mm}$ high. All cupulae were removed during processing.

Both species of cavefishes examined (Typhlichthys subterraneus and Amblyopsis spelaea) had more stiches than the two surface fishes (surface fishes $=18 \pm 3$ vs. cavefish $=25 \pm 6$; Figs. 4 and 5 ). The stitches were also longer in the dorsal-ventral dimension in T. subterraneus. All neuromasts in cavefishes had hair cells on papillae (height of papilla: $A$. spelaea $=0.55 \pm 0.006 \mathrm{~mm}$; T. subterraneus $0.73 \pm 0.16 \mathrm{~mm}$; Figs. 6 and 7 ). In $A$. spelaea, neuromasts had a surface area of $759.1 \pm 133 \mathrm{~mm}^{2}$. The sensory plate of the neuromast had a mean area of $210.8 \pm 27.0 \mathrm{~mm}^{2}$, or $27 \%$ of the surface area of the neuromast. The kinocilium was $7.0 \pm 1.1 \mathrm{~mm}$, and we were able to measure the cupula at $30.0 \pm 6 \mathrm{~mm}$. In $T$. subterraneus, mean neuromast surface area resembled surface fishes at $224 \pm 59.7 \mathrm{~mm}{ }^{2}$. The sensory plate area was $56.8 \pm 18.0 \mathrm{~mm}^{2}$, occupying $25 \%$ of the surface area of the neuromast. The length of the kinocilium was $5.4 \pm 0.9 \mathrm{~mm}$. 

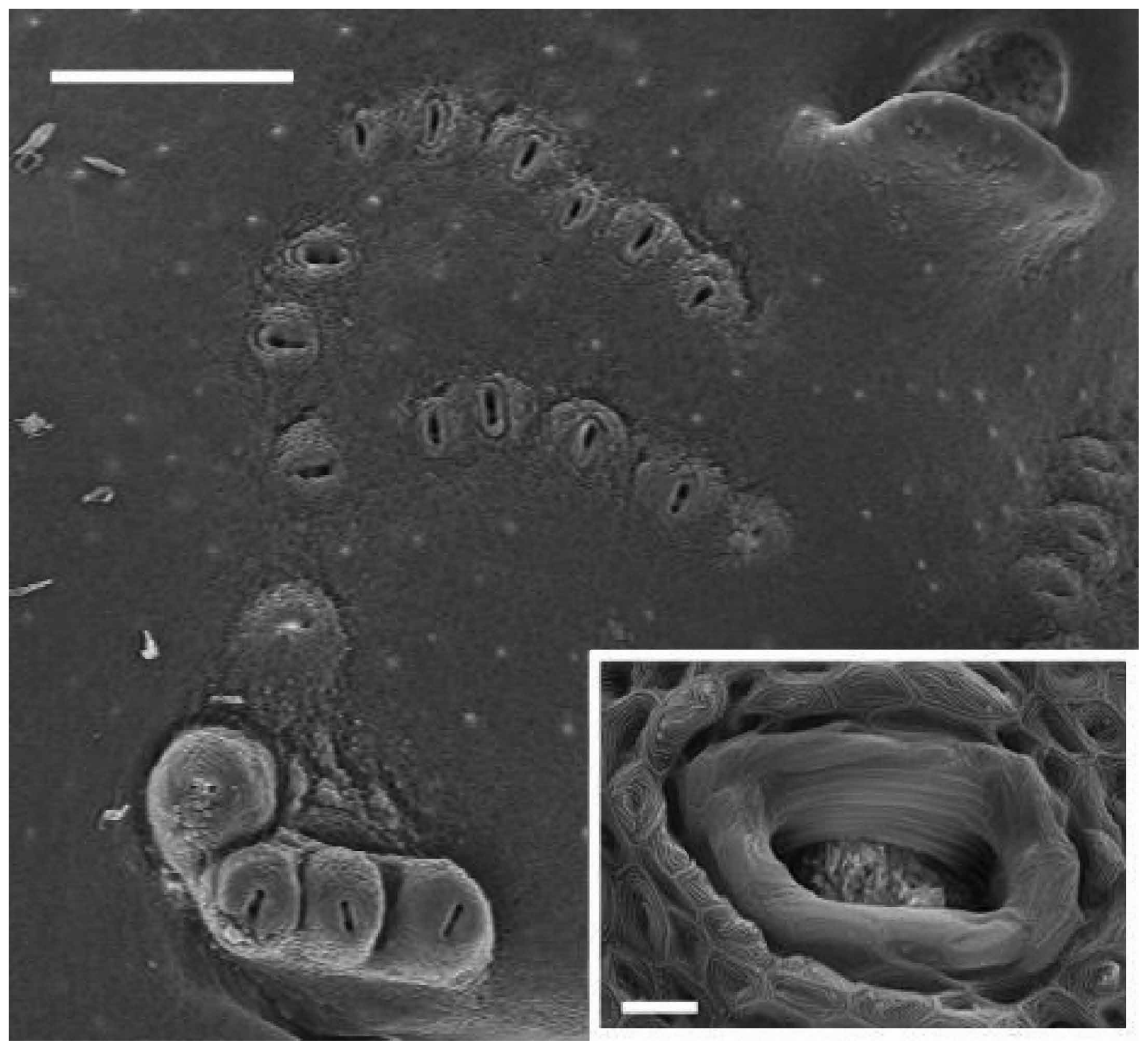

Figure 3. Receded neuromasts and neuromasts on papillae ("stitches") on the rostral end of the head of $C$. cornuta. Scale bar $250 \mu \mathrm{m}$. Insert: stereocilia after the cupula was removed. Scale bar $10 \mu \mathrm{m}$.

Amblyopsis spelaea had significantly larger neuromast areas than all other amblyopsids (HSD: P $<0.01$; Fig. 8). There was no difference among $T$. subterraneus, F. agassizii and C. cornuta (ANOVA: $P<0.0001, F=70.34$, df $=28$ ). Sensory plate areas were not significantly different between the two surface fishes but were both larger than $T$. subterraneous (HSD: $\mathrm{P}<0.01$ ), and smaller than $A$. spelaea (HSD: $\mathrm{P}<0.01$ ). Accordingly, $A$. spelaea had a larger sensory plate area than $T$. subterraneus (HSD: $\mathrm{P}<0.01$ : ANOVA: $\mathrm{P}<0.0001, \mathrm{~F}=62.53$, $\mathrm{df}=28$ ). $A$. spelaea had longer kinocilium than all other fishes (HSD: $\mathrm{P}<0.01$ ). Typhlichthys subterraneus had longer kinocilium than both $F$. agassizii and C. cornuta (HSD: $P<0.01$ ), which were similar in length (ANOVA: $P<0.0001, F=108.95$, df $=131$ ). Hair cells in the sensory plate of cavefishes also appear thicker than surface fishes.

\section{Discussion}

The successful colonization of the subterranean environment often is accompanied by the loss of vision. As eyes become less useful for detecting the environment, other sensory modalities such as mechanosensation become more prominent and even hypertrophied (Marshall, 1965). All four amblyopsid fishes included in this study had extensive 

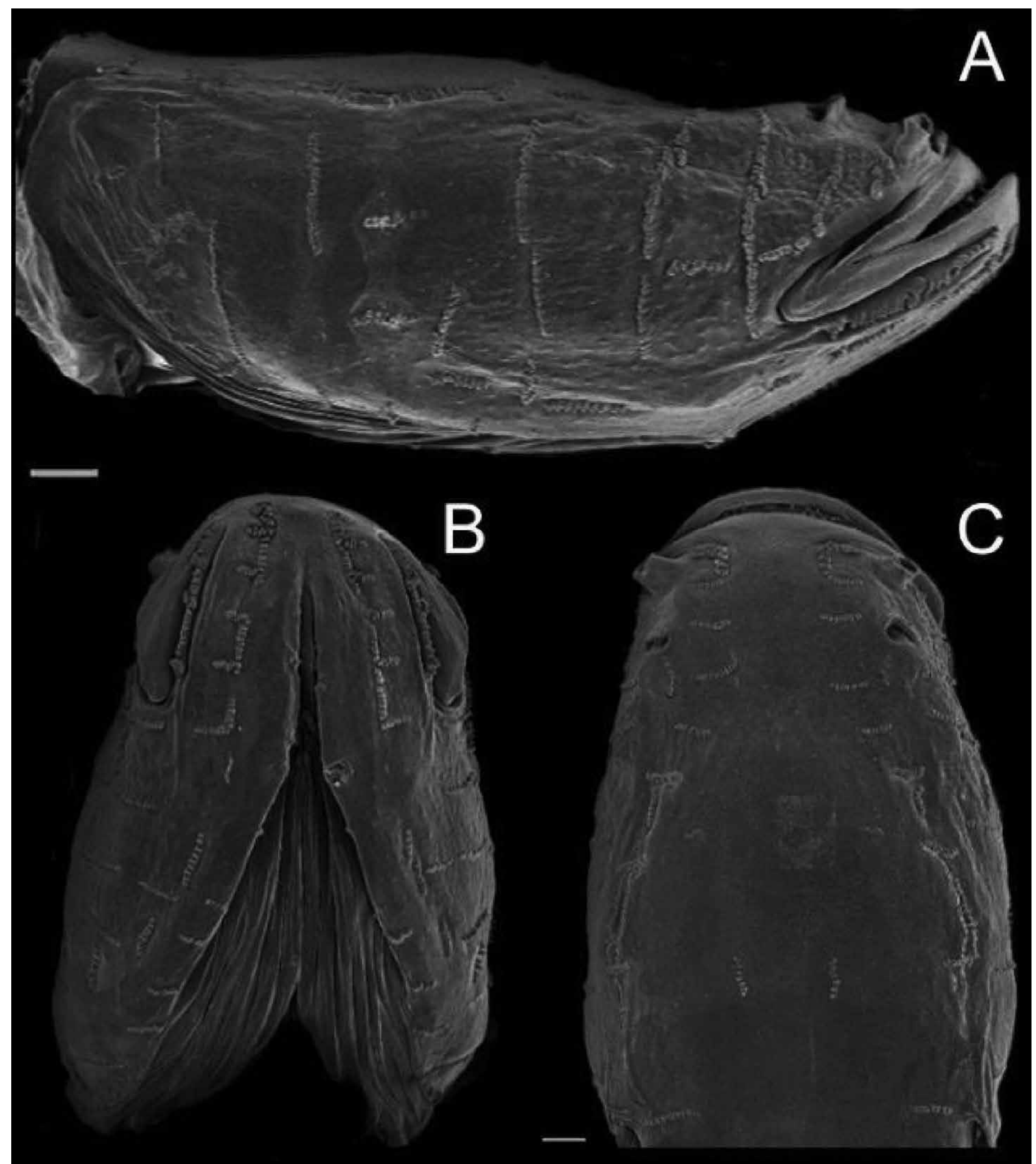

Figure 4. Lateral (A), ventral (B), and dorsal (C) SEM images of the head of Typhlichthys subterraneus. Scale bar $1 \mathrm{~mm}$.

cephalic superficial lateral line systems. Two types of cephalic superficial neuromasts were present in amblyopsids: one receded into pits into the skin and one on top of papillae, which perhaps represents different biological strategies or the result of different environmental adaptations. Both types of superficial neuromasts are arranged in dorsal-ventral stitches on the head. As most of these sets of neuromasts are also arranged with best sensitivity perpendicular to the row, they give the whole lateral line a bias for detecting water movements in the rostral-caudal direction. There were 


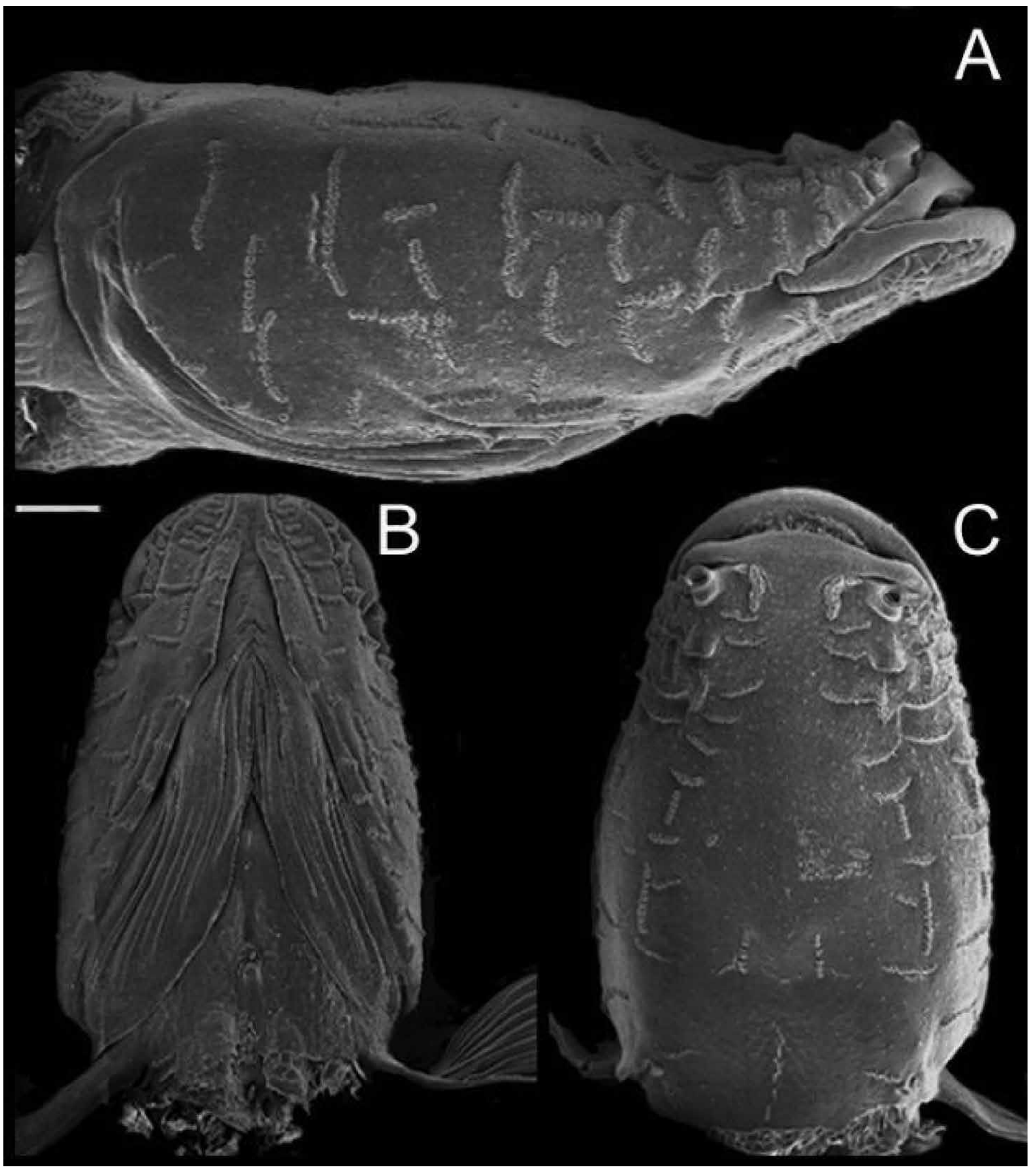

Figure 5. Lateral (A), ventral (B), and dorsal (C) SEM images of the head of Amblyopsis spelaea. Scale bar $1 \mathrm{~mm}$.

no canal neuromasts seen on the heads of all amblyopsids. In general, proliferation of superficial neuromasts in surface-dwelling fishes is accompanied by the loss of canals (Moore and Burris, 1956; Webb, 1989a).

The difference in position of cephalic superficial neuromasts between primarily surface and cave-obligate amblyopsids, i.e., receded in pits versus positioned on top of papillae, may reflect differences in microhabitat use. Both Chologaster and Forbesichthys are nocturnal benthic predators that seek shelter during the daytime and exhibit strong thig- 


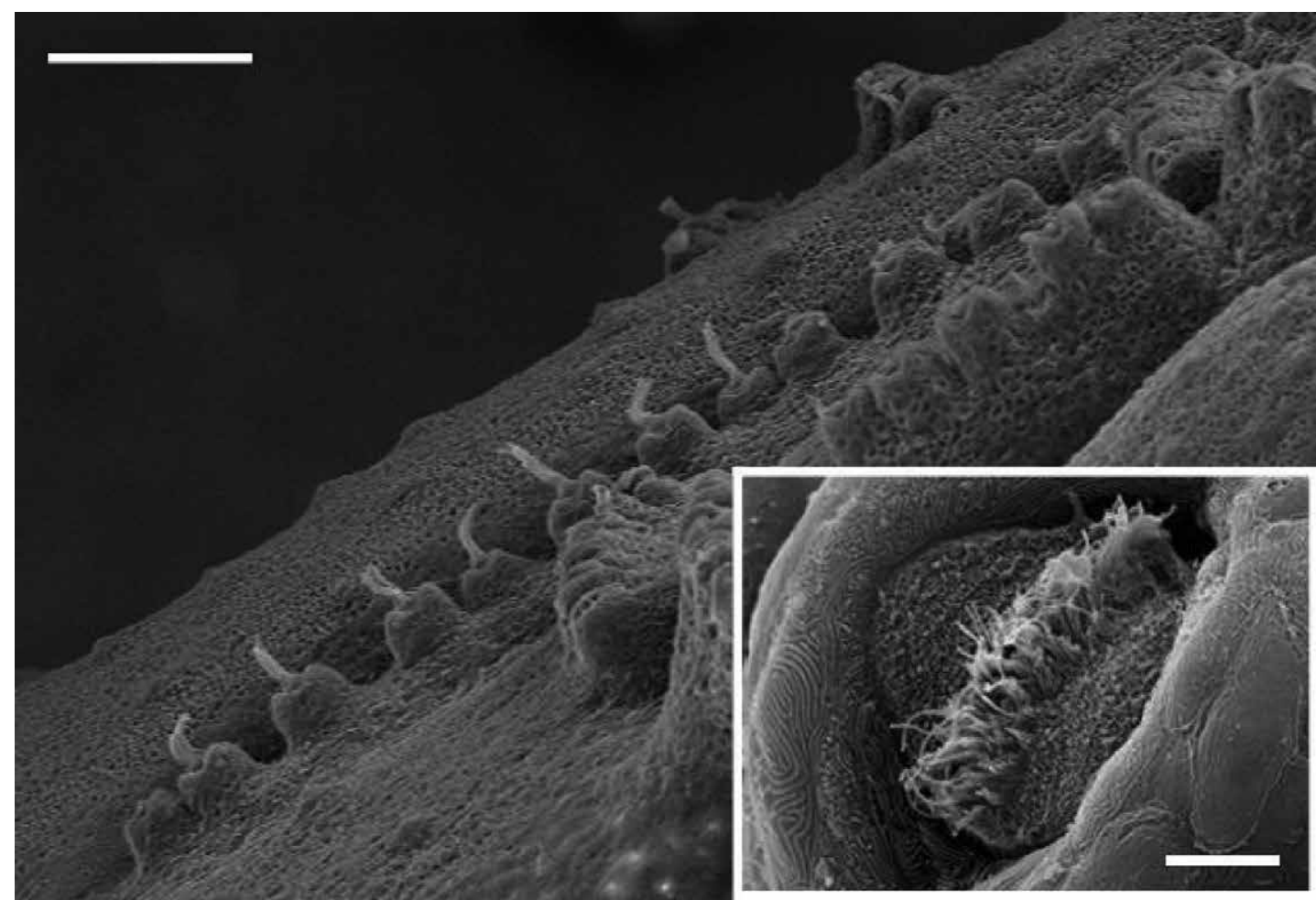

Figure 6. Neuromasts on papillae of Amblyopsis spelaea showing cupulae. Scale bar $250 \mu \mathrm{m}$. Insert: stereocilia after the cupula was removed. The kinocilium is the longest of the bundle. Scale bar $10 \mu \mathrm{m}$. motaxis (Weise, 1957; Smith and Welch, 1978; Niemiller and Poulson, 2010). Chologaster typically occurs in heavily vegetated and shaded swamps and backwater habitats where they can be collected in dense vegetation, leaf litter, and other organic debris (Cooper and Rohde, 1980; Ross and Rohde, 2003) and are rarely found in flowing water (Poulson, 1960). Likewise, Forbesichthys typically are found in dense vegetation, under rocks, or seek shelter underground in springs and caves (Weise, 1957; Smith and Welch, 1978; Niemiller and Poulson,

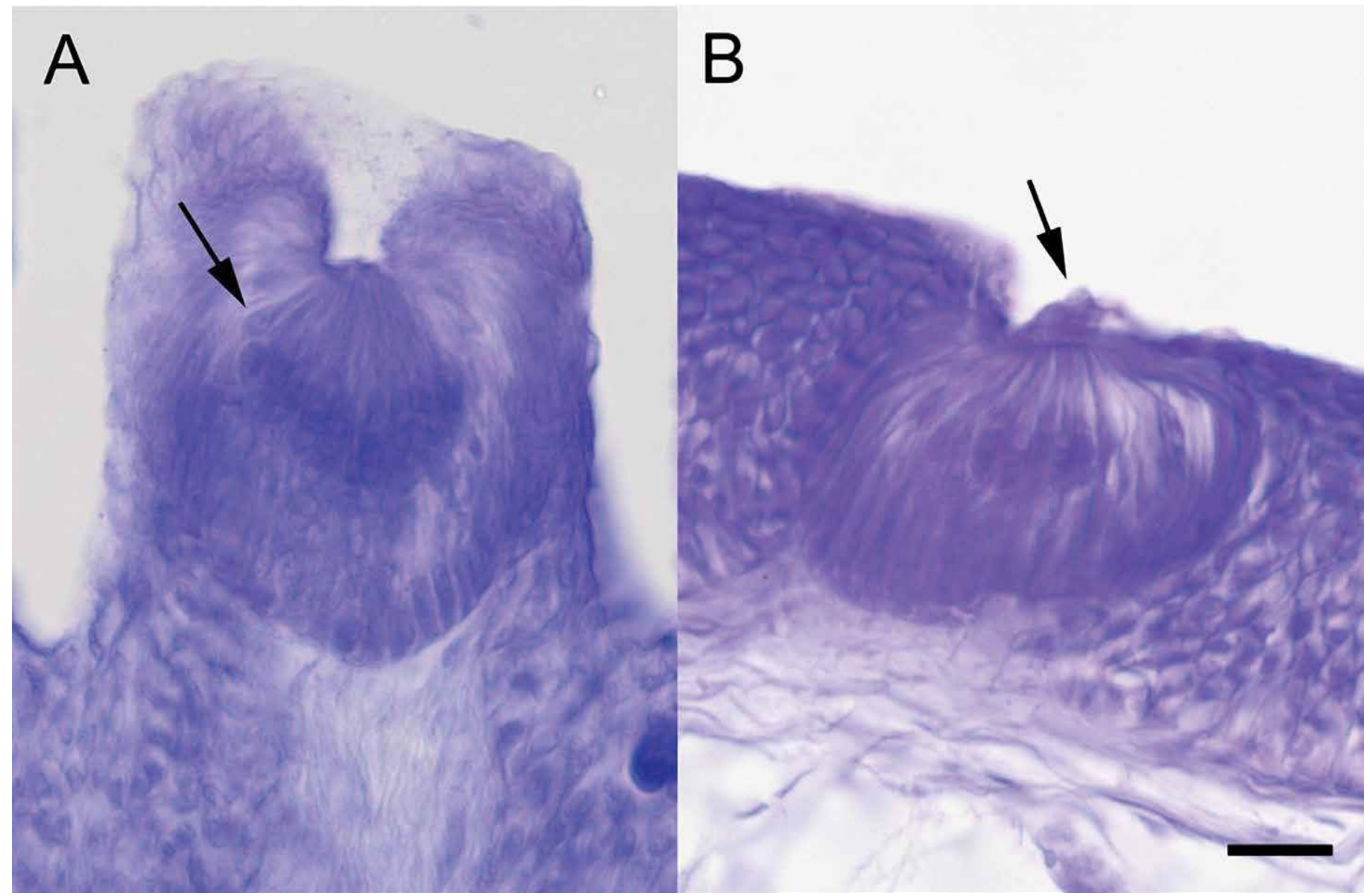

Figure 7. Cross-sections of both types of neuromasts. A) Papillate neuromast from Amblyopsis spelaea, arrow points at a single neuromast cell body. B) receded neuromast from Chologaster cornuta, arrow points at the collapsed cupula. Scale bar $100 \mu \mathrm{m}$. 

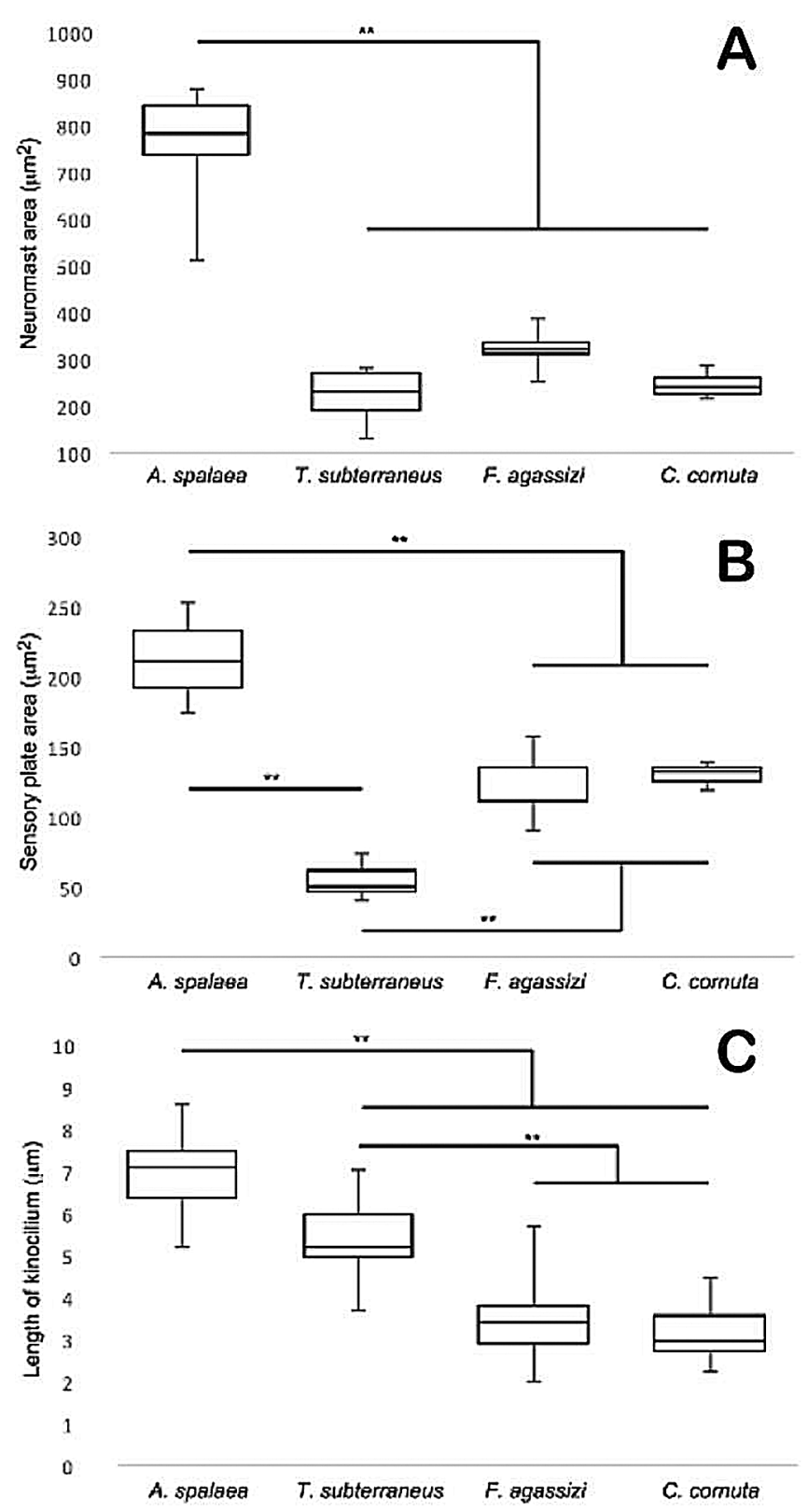

Figure 8. Comparisons of neuromast among fishes. A. spelaea has the largest superficial cephalic neuromasts of all fishes $(A)$, with the largest sensory plate area $(B)$ and the longest kinocilium (C). Both surface fishes sensory plate areas (B) and kinocelium lengths are similar to each other $(C)$. Both cavefishes are not significantly different from each other but different from both surface fishes.

ed at this type of stimulus (Douglas et al, 1998. Warrant, 2000). Nonethe "des, it appears that deep-sea fishes rely heavily on their lateral line to detect the environment and prey (Marshall 1996; Johnson and deep-sea fishes do not display schooling behaviors, which require lateral line input (Cahn et al., 1968; Greenwood et al., 2013; Kowalko et al., 2013). Another group with significant cephalic surface neuromasts are gobies (Marshall, 1996; Webb, 1989a,b), and in these fishes, many of the stitches are also vertically-oriented (Moore and Burris, 1956), biasing the detection of environmental disturbances in the rostral-caudal dimension.

Although we were not able to measure the cupula of the surface species, both cavefishes had a relatively short cupulae, roughly $30 \mu \mathrm{m}$ in length. The range of lengths of the cupula in surface fishes is variable dependent on the species and ranges between $20 \mu \mathrm{m}$ and $500 \mu \mathrm{m}$, (Mukai and Kobayashi 1993). The cupulae of Astyanax are primarily $100 \mathrm{~mm}$ in length, but some are as long as $300 \mathrm{~mm}$ (Teyke 1990). The longer cupulae in Astyanax, therefore, can in- 
crease lateral line sensitivity by protruding into the boundary layer. Astyanax and amblyopsid cavefishes appear to have different strategies to increase the height in which the cupula interacts with the water. Chologaster and Forbesichthys were not different from each other, but cavefishes ( $A$. spelaea and $T$. subterraneus) appear to encode hydrodynamic information to a different extent. Amblyopsis spelaea has the most extreme cephalic superficial neuromast phenotype.

Our study supports the general rule that mechanosensation becomes hypertrophied during cave adaptation of fishes. However, our study also suggests that hypertrophy can be variable and possibly dependent on microhabitat, developmental constraints, and/or phylogeny.

\section{References}

Ahnelt, H., Göschl, J., Dawson, M.N., and Jacobs, D.K. 2004, Geographical variation in the cephalic lateral line canals of Eucyclogobius newberryi, Teleostei, Gobiidae, and its comparison with molecular phylogeography: Folia Zoologica, v. 53, p. 358-398.

Arai, R and Kato, K., 2003, Gross morphology and evolution of the lateral line system and infraorbital bone in bitterlings, Cyprinidae, Acheilognathinae, with an overview of the lateral line system in the family Cyprinidae: Bulletin of the Museum of Tokyo University, v. 40, p. 1-42.

Armbruster, J.W., Niemiller, M.L., and Hart, P.B., 2016, Morphological evolution of the cave-, spring-, and swampfishes of the Amblyopsidae, Percopsiformes: Copeia, v. 104, p. 763-777. doi:10.1643/Cl-15-339

Baker, C.F., and Montgomery, J.C., 1999, The sensory basis of rheotaxis in the blind Mexican cave fish, Astyanax fasciatus: Journal of Comparative Physiology A, v. 184, pp. 519-527. doi:10.1007/s003590050351

Balco, G., Stone, J.O., and Mason, J.A., 2005, Numerical ages for Plio-Pleistocene glacial sediment sequences by $26 \mathrm{Al} / 10 \mathrm{Be}$ dating of quartz in buried paleosols: Earth and Planetary Science Letters, v. 232, p. 179-191, doi:10.1016/j.epsl.2004.12.013.

Batchelor, G.K., 1967, An Introduction to Fluid Dynamics: Cambridge University Press, New York, 658 p.

Beckmann, M., Erős, T., Schmitz, A., and Bleckmann, H., 2010, Number and distribution of superficial neuromasts in twelve common European cypriniform fishes and their relationship to habitat occurrence: International Review of Hydrobiology, v. 95, p. 273-284. doi:10.1002/ iroh.200911185

Bergman, L.M.R., 2004. The cephalic lateralis system of cardinalfishes, Perciformes: Apogonidae, and its application to the taxonomy and systematics of the family: [Ph.D. Thesis], University of Hawaii at Manoa, U.S, 373 p.

Blaxter, J.H.S., Gray, J.A.B., and Best, A.C.G., 1983, Structure and development of the free neuromasts and lateral line system of the herring: Journal of the Marine Biological Association U.K., v. 63, p. 247-260. doi:10.1017/S0025315400070648

Bleckmann, H., 1994, Reception of hydrodynamic stimuli: In Aquatic and Semiaquatic Animals: Rathmayer, W., ed., Progress in Zoology, v. 41, p. $1-115$.

Cahn, P.H., Shaw, E., and Atz, E.H., 1968, Lateral-line histology as related to the development of schooling in the atherinid fish, Menidia: Bulletin of Marine Science, v. 18, p. 660-670.

Carton, A.G., and Montgomery, J.C., 2004, A comparison of lateral line morphology of blue cod and torrentfish: two sandperches of the family Pinguipedidae: Environmental Biology of Fishes, v. 70, p.123-131. doi:10.1023/B:EBFI.0000029340.57735.f8

Chakrabarty, P., Prejean, J.A., and Niemiller, M.L., 2014, The Hoosier cavefish, a new and endangered species (Amblyopsidae, Amblyopsis) from the caves of southern Indiana: ZooKeys, v. 412, p. 41. doi:10.3897/zookeys.412.7245

Coombs, S., Janssen, J., and Webb, J.F., 1988, Diversity of lateral line systems: evolutionary and functional considerations: In Sensory Biology of Aquatic Animals, Atama, J. Fay, R.R., Popper, A.N., and Travolga W.N., eds, p. 553-593. Springer, New York, NY.

Coombs, S., and Montgomery, J., 1994, Function and evolution of superficial neuromasts in an Antarctic notothenioid fish: Brain, Behavior and Evolution, v. 44, p. 287-298. doi:10.1159/000113590

Cooper, J.E., and Rohde F.C., 1980, Chologaster cornuta Agassiz: In Lee, D.S., Gilbert, C.R., Hocutt C.H., Jenkins, R.E., McAllister, D.E., and Stauffer, J.R., Jr., eds., Atlas of North American Freshwater Fishes, orth Carolina State Museum of Natural History, Raleigh, North Carolina, v. $1,444 \mathrm{p}$.

Coughlin D.J., and Strickler J.R., 1990, Zooplankton capture by a coral reef fish: an adaptive response to evasive prey: Environmental Biology of Fishes v. 29, p. 5-42. doi:10.1007/BF00000566

Ćurčić-Blake, B., and van Netten, S.M., 2006, Source location encoding in the fish lateral line canal: Journal of Experimental Biology, v. 209, p.1548-1559. doi:10.1242/jeb.02140

de Perera, T.B., 2004, Fish can encode order in their spatial map: Proceedings of the Royal Society of London B: Biological Sciences, v. 271, p. 2131-2134. doi:10.1098/rspb.2004.2867

Denton, E.J., and Gray, J.A., 1989, Some observations on the forces acting on neuromasts in fish lateral line canals: in Coombs, S., Gorner P. and Munz, H. eds, The mechanosensory lateral line, Springer, New York, NY, p. 229-246. doi:10.1007/978-1-4612-3560-6_11

Dezfuli, B.S., Magosso, S., Simoni, E., Hills, K., and Berti, R., 2009, Ultrastructure and distribution of superficial neuromasts of blind cavefish, Phreatichthys andruzzii, juveniles: Microscopy research and technique, v. 72, p. 665-671. doi:10.1002/jemt.20714

Diaz, J.P., Prié-Granié, M., Kentouri, M., Varsamos, S., and Connes, R., 2003, Development of the lateral line system in the sea bass: Journal of Fish Biology v. 62, p. 24-40.

Douglas, R.H., Partridge, J.C., and Marshall, N.J., 1998, The eyes of deep-sea fish I: lens pigmentation, tapeta and visual pigments: Progress in retinal and eye research v. 17, p. 597-636. doi:10.1046/j.1095-8649.2003.00004.x

Faucher, K., Parmentier, E., Becco, C., Vandewalle, N., and Vandewalle, P., 2010, Fish lateral system is required for accurate control of shoaling behaviour: Animal Behaviour, v. 79, p. 679-687. doi:10.1016/j.anbehav.2009.12.020

Gosline, W.A., 1974, Certain lateral line canals of the head in cyprinid fishes, with particular reference to the derivation of North American forms: Japan Journal of Ichthyology, v. 21, p. 9-15.

Greenwood, A.K., Wark, A.R., Yoshida, K., and Peichel, C.L., 2013, Genetic and neural modularity underlie the evolution of schooling behavior in threespine sticklebacks: Current Biology, v. 23, p. 1884-1888. doi:10.1016/j.cub.2013.07.058

Hassan, E.S., 1985, Mathematical analysis of the stimulus of the lateral line organ: Biological Cybernetics, v. 52, p. 23-36.

Higgs, D.M., and Fuiman, L.A., 1998, Associations between sensory development and ecology in three species of clupeoid fish: Copeia, v. 1, p.133-144. doi:10.1007/BF00336932

Hoekstra, D., and Janssen, J., 1985, Non-visual feeding behavior of the mottled sculpin, Cottus bairdi, in Lake Michigan: Environmental Biology of Fishes v. 12, p. 111-117. doi:10.1007/BF00002763

Hoekstra, D., and Janssen J., 1986, Receptive field of the mottled sculpin lateral line for Daphnia and a vibrating inert stimulus: Copeia, v. 9, p. 
1-96. doi:10.2307/1444893

Janssen, J., 1990, Localization of substrate vibrations by the mottled sculpin, Cottus bairdi: Copeia, v. 1, p. 349-355. doi:10.2307/1446340

Janssen, J., 1996, Use of the lateral line and tactile senses in feeding in four antarctic notothenioid fishes: Environmental Biology of Fishes, v. 47, p. 1-64. doi:10.1007/BF00002379

Janssen, J., 2004, Lateral line sensory ecology: In von der Emde, G., Mogdans, J. and Kappr, B.G., eds. The Senses of Fish, Springer, Dordrecht, p. 231-264. doi:10.1007/978-94-007-1060-3_11

Janssen, J., and Corcoran, J., 1998, Distance determination via the lateral line in the mottled sculpin: Copeia, v. 1, p. 657-661. doi:10.2307/1447795

Janssen, J., Jones, W.R., Whang, A., and Oshel, P.E., 1995, Use of the lateral line in particulate feeding in the dark by juvenile alewife, Alosa pseudoharengus: Canadian Journal of Fish Aquatic Sciences, v. 52, p. 358-363. doi:10.1139/f95-037

Janssen, J., Sideleva, V., and Biga, H., 1999, Use of the lateral line for feeding in two Lake Baikal sculpins: Journal of Fish Biology, v. 54, p. 404-416. doi:10.1111/j.1095-8649.1999.tb00839.x

Jiang, Y., Fu, J., Zhang, D., and Zhao, Y., 2016, Investigation on the lateral line systems of two cavefish: Sinocyclocheilus macrophthalmus and S. microphthalmus (Cypriniformes: Cyprinidae). Journal of Bionic Engineering, v. 13, p. 108-114. doi:10.1016/S1672-6529(14)60164-5

Johnson, G.D., Paxton, J.R., Sutton, T.T., Satoh, T.P., Sado, T., Nishida, M., and Miya, M., 2009, Deep-sea mystery solved: astonishing larval transformations and extreme sexual dimorphism unite three fish families: Biology Letters, v. 5, p. 235-239. doi:10.1098/rsbl.2008.0722

Kalmijn, A.J., 1989, Functional evolution of lateral line and inner ear sensory systems: In Coombs, S., Gorner P. and Munz, H. eds.,The Mechanosensory Lateral Line, Springer, New York, NY Springer, New York, NY., p. 187-215. doi:10.1007/978-1-4612-3560-6_9

Kowalko, J.E., Rohner, N., Rompani, S.B., Peterson, B.K., Linden, T.A., Yoshizawa, M., Kay, E.H., Weber, J., Hoekstra, H.E., Jeffery, W.R., and Borowsky, R., 2013, Loss of schooling behavior in cavefish through sight-dependent and sight-independent mechanisms: Current Biology, v.23, p. 1874-1883. doi:10.1016/j.cub.2013.07.056

Kuiper, J.W., 1967, Frequency characteristics and functional significance of the lateral line organ: In Cahn, P.H., ed., Lateral Line Detectors, Indiana University Press, Bloomington, p. 105-121.

Kurawaka, K., 1977, Cephalic lateral-line systems and geographical distribution in the genus Tribolodon, Cyprinidae: Japanese Journal of Ichthyology, v. 24, p. 167-175.

Lamb, H., 1945, Hydrodynamic: 6th Edition, Dover Publications, New York, 738 p.

Marshall, N.B., 1965, Systematic and biological studies of the macrourid fishes, Anacanthini-Teleostii: In Deep Sea Research and Oceanographic Abstracts, v. 123, p. 299-322. doi:10.1016/0011-7471(65)90004-5

Marshall, N.J., 1996, Vision and sensory physiology. The lateral line systems of three deep-sea fish: Journal of Fish Biology, v. 49, p. $239-258$. doi:10.1111/j.1095-8649.1996.tb06079.x

McHenry, M.J., Feitl, K.E., Strother, J.A., and Van Trump, W.J., 2009, Larval zebrafish rapidly sense the water flow of a predator's strike: Biology Letters, v. 5, p. 477-479. doi:10.1098/rsbl.2009.0048

McHenry, M.J., Strother, J.A., and Van Netten, S.M., 2008, Mechanical filtering by the boundary layer and fluid-structure interaction in the superficial neuromast of the fish lateral line system: Journal of Comparative Physiology A, v. 194, p. 795-810. doi:10.1007/s00359-008-0350-2

Montgomery, J.C., Baker, C.F., and Carton, A.G., 1997, The lateral line can mediate rheotaxis in fish: Nature, v. 389, p. 960. doi:10.1038/40135

Montgomery, J.C., Coombs, S., and Baker, C.F., 2001, The mechanosensory lateral line system of the hypogean form of Astyanax fasciatus: Environmental Biology of Fishes, v. 62, p. 87-96. doi:10.1007/978-94-015-9795-1_5

Montgomery, J., Coombs, S., and Janssen, J., 1994, Form and function relationships in lateral line systems: comparative data from six species of Antarctic notothenioid fish: Brain, Behavior and Evolution, v. 44, p. 299-306. doi:10.1159/000113591

Moore, G.A., and Burris, W.E., 1956, Description of the lateral-line system of the pirate perch, Aphredoderus sayanus: Copeia, v. 1, p.18-20. doi:10.2307/1439238

Mukai, Y. and Kobayashi, H., 1993, Extremely long cupulae of embryonic neuromasts in cyprinid fish: Copeia, v. 4, p. $1157-1159$. doi:10.2307/1447101

Müller, U. and Schwartz, E., 1982, Influence of single neuromasts on prey localizing behavior of the surface feeding fish, Aplocheilus lineatus: Journal of Comparative Physiology A: Neuroethology, Sensory, Neural, and Behavioral Physiology, v. 149, p. 399-408. doi:10.1007/ BF00619155

Nelson, J.S., 1972, Cephalic sensory canals, pitlines, and the classification of esocoid fishes, with notes on galaxiids and other teleosts: American Museum Novitates v. 2492, p.1-49.

Northcutt, G. A. (1989). The phylogenetic distribution and innervation of craniate mechanoreceptive lateral lines. In The Mechunosensory Loferal Line (Coombs, S., Gomer, P. \& Munz H., eds), pp. 17-78. New York: Springer-Verlag.

Niemiller, M.L., Fitzpatrick, B.M., Shah, P., Schmitz, L., and Near, T.J., 2013a, Evidence for repeated loss of selective constraint in rhodopsin of amblyopsid cavefishes, Teleostei: Amblyopsidae: Evolution, v. 67, p. 732-748. doi:10.1111/j.1558-5646.2012.01822.x

Niemiller, M.L., McCandless J.R., Reynolds R.G., Caddle J., Near T.J., Tillquist C.R., Pearson, W.D., and Fitzpatrick, B.M., 2013b, Effects of climatic and geological processes during the Pleistocene on the evolutionary history of the northern cavefish, Amblyopsis spelaea, Teleostei: Amblyopsidae: Evolution, v. 67, p. 41011-1025. doi:10.1111/evo.12017

Niemiller, M.L., and Poulson, T.L., 2010, Subterranean fishes of North America: Amblyopsidae: Biology of subterranean fishes, v. 169 , p. 280. doi:10.1201/EBK1578086702-c7

Niemiller, M.L., and Soares, D., 2015, Cave environments: In Riesch, R., Tobler, M., Martin Plath, M., eds., Extremophile Fishes, p. 161-191, Springer, Cham. doi:10.1007/978-3-319-13362-1

Parin, N., Astakhov, D., 1982, Studies on the acoustico-lateralis system of beloniform fishes in connection with their systematics: Copeia, v. 1, p. 276-291. doi:10.2307/1444606

Partridge, B.L., Pitcher, T., Cullen, J.M., and Wilson, J., 1980, The three-dimensional structure of fish schools: Behavioral Ecology and Sociobiology, v. 6, p. 277-288. doi:10.1007/BF00292770

Pitcher, T.J., 2001, Fish schooling: implications for pattern in the oceans and impacts on human fisheries: In: Steele, J.H., Turekian, K.K., and Thorpe, S.A., eds., Encyclopedia of Ocean Sciences, London. Academic Press, p. 975-987. doi:10.1006/rwos.2001.0022

Poulson, T.L., 1960, Cave adaptation in Amblyopsidae fishes. [PhD thesis], Department of Zoology, University of Michigan, Ann Arbor. University Microfilms, $2787 \mathrm{p}$.

Poulson, T.L., 1963, Cave adaptation in amblyopsid fishes: American Midland Naturalist, p. 257-290. doi:10.2307/2423056

Poulson, T.L., 2001, Adaptations of cave fishes with some comparisons to deep-sea fishes: Environmental Biology of Fishes, v. 62, p. 345-364. 
doi:10.1007/978-94-015-9795-1_28

Reno, N.W., 1966, The infraorbital canal, its lateral line ossicles and neuromasts, in the minnows Notropis volucellus and N. buchanani: Copeia, v. 1 , p. $403-413$. doi:10.2307/1441059

Ross, S.W. and Rohde, F.C., 2003. Life history of the swampfish from a North Carolina stream: Southeastern Naturalist, v. 2, p. 105-120. doi:10.1656/1528-7092(2003)002[0105:LHOTSF]2.0.CO;2

Schlichting, H., 1979, Boundary-Layer Theory. McGraw-Hill, New York., 815 p.

Schwarz, J.S., Reichenbach, T. and Hudspeth, A.J., 2011, A hydrodynamic sensory antenna used by killifish for nocturnal hunting: Journal of Experimental Biology, v. 214, p. 1857-1866. doi:10.1242/jeb.051714

Schmitz, A., Bleckmann, H. and Mogdans, J., 2014, The lateral line receptor array of cyprinids from different habitats: Journal of morphology, v. 275, p. 357-370. doi:10.1002/jmor.20219

Smith, P.W. and N.M. Welch. 1978, A summary of the life history and distribution of the spring cavefish, Chologaster agassizi, Putnam, with population estimates for the species in southern Illinois: Illinois Natural History Survey Biological Notes, v. 104, p. 1-8.

Soares, D. and Niemiller, M.L., 2013, Sensory adaptations of fishes to subterranean environments: BioScience, v. 63, p. 274-283. doi:10.1525/ bio.2013.63.4.7

Stephens, R.R., 1985, The lateral line system of the gizzard shad, Dorosoma cepedianum Lesueur, Pisces: Clupeidae: Copeia, v. 1, p. 540-556. doi:10.2307/1444742

Sutterlin, A.M., and Waddy, S., 1975, Possible role of the posterior lateral line in obstacle entrainment by brook trout, Salvelinus fontinalis: Journal of the Fisheries Board of Canada, v. 32, p. 2441-2446. doi:10.1139/f75-281

Teyke, T., 1988, Flow field, swimming velocity and boundary layer: parameters which affect the stimulus for the lateral line organ in blind fish: Journal of Comparative Physiology A: Neuroethology, Sensory, Neural, and Behavioral Physiology, v. 163, p. 53-61. doi:10.1007/ BF00611996

Teyke, T., 1990, Morphological differences in neuromasts of the blind cave fish Astyanax hubbsi and the sighted river fish Astyanax mexicanus: Brain Behavior and Evolution, v. 35, p. 23-30. doi:10.1159/000115853

Tittel, G., Müller, U. and Schwartz, E., 1984, Determination of stimulus direction by the topminnow Aplocheilus lineatus: In Varju, D., and Schnitzler, H.U., eds., Localization and Orientation in Biology and Engineering, Springer, Berlin, Heidelberg, p. 69-72. doi:10.1007/978-3-64269308-3_14

van Netten, S.M., 2006, Hydrodynamic detection by cupulae in a lateral line canal: functional relations between physics and physiology: Biological Cybernetics, v. 94, p. 67-85. doi:10.1007/s00422-005-0032-x

van Netten, S.M., and Kroese, A.B., 1989, Hair cell mechanics controls the dynamic behaviour of the lateral line cupula: In Wilson, J ed., Cochlear Mechanisms: Structure, Function, and Models, Springer U.S., p. 47-55. doi:10.1007/978-1-4684-5640-0_6

Van Trump, W.J. and McHenry, M.J., 2013, The lateral line system is not necessary for rheotaxis in the Mexican blind cavefish, Astyanax fasciatus: Integrative and Comparative Biology, v. 53, p. 799-809. doi:10.1093/icb/ict064

Warrant, E., 2000, The eyes of deep-sea fishes and the changing nature of visual scenes with depth: Philosophical Transactions of the Royal Society of London B: Biological Sciences, v. 355, p. 1155-1159. doi:10.1098/rstb.2000.0658

Webb, J.F., 1989a, Developmental constraints and evolution of the lateral line system in teleost fishes: In Coombs, S., Gorner P., and Munz, H., eds, The Mechanosensory Lateral Line, Springer, New York, NY, p. 79-97. doi:10.1007/978-1-4612-3560-6_4

Webb, J.F., 1989b, Gross morphology and evolution of mechanoreceptive lateral line system in teleost fishes: Brain Behavior Evolution, v. 33, p. 34-53. doi:10.1159/000115896

Weise, J.G., 1957. The spring cave-fish, Chologaster papilliferus, in Illinois: Ecology, v. 38, p. 195-204. doi:10.2307/1931678

Yoshizawa, M., Gorički, Š., Soares, D., and Jeffery, W.R., 2010, Evolution of a behavioral shift mediated by superficial neuromasts helps cavefish find food in darkness: Current Biology, v. 20, p. 1631-1636. doi:10.1016/j.cub.2010.07.017

Yoshizawa, M., Jeffery, W.R., van Netten, S.M., and McHenry, M.J., 2014, The sensitivity of lateral line receptors and their role in the behavior of Mexican blind cavefish, Astyanax mexicanus: Journal of Experimental Biology, v. 217, p. 886-895. doi:10.1242/jeb.094599 